\title{
Breastfeeding promotion and support strategies based on Paulo Freire's epistemological categories ${ }^{1}$
}

\section{(1)}

\author{
Estratégias de promoção à amamentação \\ centrada nas categorias epistemológicas \\ de Paulo Freire
}

Francisca Márcia Pereira LINHARES²

Cleide Maria PONTES²

Mônica Maria OSÓRIO3

\author{
MOnica Maria OSORIOও
}

A B S T R A C T

\section{Objective}

This study identified strategies for promoting breastfeeding involving pregnant women, breastfeeding women and actors of the social support network for the breastfeeding process.

\section{Methods}

This qualitative study was guided by action research and the focal group technique to collect data. Focal Group 1 consisted of four pregnant and six breastfeeding women; Focal Group 2 consisted of six family members; and Focal Group 3 consisted of thirteen health professionals. The focal groups were guided by the following questions: What breastfeeding promotion and support actions should be done? How should they be performed? Who should perform them? The conversation sunder went thematic content analysis and were interpreted in the light of Paulo Freire's theoretical constructs: dialogue, ethics and problematization.

\section{Results}

Four themes were emerged from the conversations: dialogue-based educational actions involving the social support network during the vital cycle; educational actions in schools; educational actions in the media; ongoing counseling at Family Health Units.

\footnotetext{
1 Article based on the thesis of FMP LINHARES intitled: "Breastfeeding promotion in the light of Paulo Freire" (Promoção da amamentação à luz do referencial de Paulo Freire). Universidade Federal de Pernambuco; 2011.

2 Universidade Federal de Pernambuco, Centro de Ciências da Saúde, Programa de Pós-Graduação em Enfermagem. Av. Prof. Moraes do Rego, s/n., $1^{\circ}$ andar, Bloco A do Hospital das Clínicas, Cidade Universitária, 50670-901, Recife, PE, Brasil. Correspondence to/Correspondência para: FMP LINHARES. E-mail: <marciapl@terra.com.br>.

3 Universidade Federal de Pernambuco, Centro de Ciências da Saúde, Programa de Pós-Graduação em Nutrição. Recife, PE, Brasil.
} 
126 | FMP LINHARES et al.

\section{Conclusion}

The constructed strategies were centered on dialogue and active listening. Both should be present during the entire vital cycle and in the Family Health Strategy, and involve all actors of the social support network. These strategies may disrupt the unidirectional transmission of the educational practices that promote breastfeeding.

Indexing terms: Breast feeding. Family health. Health education. Health promotion.

\section{R E S U M O}

\section{Objetivo}

Identificar estratégias de promoção ao aleitamento materno envolvendo gestantes, nutrizes e atores da rede de apoio social no processo da amamentação.

\section{Métodos}

Estudo qualitativo conduzido pela pesquisa-ação utilizando a técnica do grupo focal para a coleta de dados. Participaram do Grupo Focal 1, 4 gestantes e 6 nutrizes, do Grupo Focal 2, 6 familiares e do Grupo Focal 3, 13 profissionais da saúde. Os grupos focais foram guiados pelas seguintes questões norteadoras: Quais as ações de promoção e apoio à amamentação que devem ser realizadas? Como devem ser realizadas? Quem deve realizá-las? As falas foram submetidas à análise de conteúdo, na modalidade temática e interpretadas à luz dos constructos teóricos de Paulo Freire: diálogo, ética e problematização.

\section{Resultados}

Da análise das falas emergiu quatro temas: ações educativas centradas no diálogo, envolvendo a rede de apoio social durante o ciclo vital; ações educativas nas escolas; ações educativas inseridas nos meios de comunicação; aconselhamento contínuo na Unidade de Saúde da Família.

\section{Conclusão}

As estratégias construídas foram centradas no diálogo e na escuta ativa, que deverão estar presente em todo o ciclo vital e, na Estratégia Saúde da Família, com envolvimento de todos os atores da rede de apoio social. Estas estratégias poderão romper a transmissão vertical da prática educativa na promoção do aleitamento materno.

Termos de indexação: Amamentação. Saúde da família. Educação em saúde. Promoção da saúde.

\section{NTRODUCTION}

Global actions to encourage breastfeeding are supported by three pillars: promotion, support and protection. Important breastfeeding promotion actions are the World Breastfeeding Week, National Human Milk Donation Day and the Human Milk Banks Network'. In 2008, the Brazilian Ministry of Health launched a new strategy for promoting breastfeeding in primary care, the Breastfeed Brazil Network, which proposes an interdisciplinary work based on the principles of ongoing education².

The pro-breastfeeding actions are a reality in the world and Brazil. However, these strategies are generally guided by knowledge produced exclusively by health professionals through unidirectional educational actions, reinforcing the idea that the mother is the only person responsible for the breastfeeding practice ${ }^{3}$. Generally, effective discussion with the protagonists of this practice does not happen and breastfeeding promotion policy is permeated by the attempt to shape the woman's behavior for her to choose to breastfeed.

Consequently, participative educational actions could promote reflection and allow the relevant actors to participate more actively. This requires guiding the experiences, knowing how to listen and showing mutual respect. This process will promote the creation of bonds and conscious decision making without imposition ${ }^{4}$.

In this sense, dialogue is a powerful tool for transforming human beings into active individuals, authors of their own story. In dialogic 
education practice, people are available for listening and interpersonal relationships are bidirectional, participative and humanized. In this space, one who teaches is dialectically educated because knowledge is not singular. Different bits of knowledge complement each other, often giving a sensation of unfinishedness, since there is always something requiring reformulation ${ }^{5}$. Therefore, daily life experiences are problematized in this collective construction and should be the starting point for knowing reality, and for unveiling and interacting with the world of the individuals involved. This is possible thanks to intercommunication in the educational process ${ }^{4}$.

Ethics is present in educational action when health professionals provide a democratic environment, free from prejudice and discrimination. Participants' opinions are respected and everyone is seen as social individuals who have their own values, habits and culture ${ }^{6}$.

As a result, it is important to create breastfeeding promotion strategies that have been previously discussed with pregnant women, breastfeeding women, family members and health professionals. Incorporation an approach that emphasizes experiences and bits of knowledge of the people involved is a necessary stimulus for individual and group change.

In this process, dialogue, problematization and ethics are essential for identifying the impressions, opinions, feelings and bits of knowledge of the social actors. These Freirean suppositions propose a new pedagogical concept, recognizing the historical, social, political and economic character of those involved ${ }^{4}$.

Considering these aspects, the present study aims to identify breastfeeding promotion strategies that involve pregnant women, breastfeeding women and social support network actors in the breastfeeding process.

\section{METHODS}

This is a descriptive, exploratory study using the qualitative approach done in the Family
Health Unit João Rodrigues in the city of Recife (PE), Brazil. The participants were health professionals, pregnant women, breastfeeding women and family members of the latter two. This study is part of a research action called "Breastfeeding promotion in the light of Paulo Freire", and followed the methodological sequence suggested by Le Boterf ${ }^{7}$ for participatory research.

Action research is a type of social research linked to actions required to solve a public problem. These actions are developed by the study researchers and participants together and are grounded on co-responsibility 8 .

An initial survey was done with 30 health professionals, 101 breastfeeding women, 66 pregnant women and 26 family members to identify their socioeconomic and cultural profiles, experiences, feelings and theoretical knowledge about breastfeeding and to assess their professional breastfeeding promotion practices.

The results of this preliminary survey were presented at a meeting with the participants that showed up at the previously arranged location, time and date. The information was disclosed separately to the health professionals and to the other participants, namely the pregnant and breastfeeding women and their family members. Three focal groups were structured from these meetings for the critical analysis of the problems considered priorities, corresponding to Le Boterf's? third phase. Focal group is a special type of group whose main objective is to encourage the participants to discuss a certain issue. It is the ideal technique for exploring experiences, opinions, concepts and group construction?.

The Focal Group 1 (FG1) consisted of four pregnant women and six breastfeeding women. The Focal Group 2 (FG2) consisted of six family members of the pregnant and breastfeeding women. The Focal Group 3 (FG3) consisted of thirteen health professionals of whom seven were community health agents, two were nursing assistants, three were nurses and one was a physician. Participant recruitment took into 
consideration their interest on the theme and desire to contribute to the transformation of the practice.

The focal groups met between August and October of 2009 in the hall of the local church and each session lasted on average one and a half hours. The number of focal group sessions was established by the information saturation criterion $^{10}$, so four sessions took place. The focal group consisted of one moderator, one observer and one reporter. The function of the moderator was to coordinate the group and keep the participants focused on the study theme. The observer was responsible for taking down the verbal and nonverbal behaviors during the sessions and the reporter was in charge of taping the discussion using a digital voice recorder ${ }^{9}$.

At the beginning of the first session of each group, the moderator introduced himself and the other two collaborators of the team (observer and reporter) and disclosed the objectives of the study and focal group. Next, the moderator asked the participants for permission to tape the session, guaranteeing the anonymity of the collected information. A verbal agreement was established with the participants where all of them agreed to listen carefully to each other, take turns talking, not discuss the content of the focal group session elsewhere and respect everyone's opinions and feelings.

A photograph of a singer breastfeeding was used for introducing the theme, beginning the construction and association of ideas and encouraging group participation. The discussion was guided by the following questions: What breastfeeding promotion and support actions should be done? How should breastfeeding promotion and support actions be performed? Who should perform them? After each session, the entire session was transcribed. Next, the transcriptions and collected information were read and reread. The statements were understood and analyzed under a single context based on meaningful and repeated words and phrases. The core meanings were condensed and codified.
These codifications emerged as subcategories and thematic categories ${ }^{11}$.

Paulo Freire's epistemological categories dialogue, ethics and problematization - permeate the shared process of constructing breastfeeding promotion and support strategies, helping to interpret the themes ${ }^{4}$.

This study was approved by the Hospital Agamenon Magalhães Research Ethics Committee under protocol number 150/08 in April 2008 and all participants signed a Free and Informed Consent Form, respecting the norms of Resolution 196/96 issued by the Human Research Ethics Committee of the National Health Council.

RES U LT S

The women in FG1 were 14 to 36 years old. Five of them had not finished elementary school and nearly all of them were housewives. Their household incomes were at or below one minimum salary. FG2 consisted of six women, two mothers of pregnant women, one mother of a breastfeeding woman, two grandmothers of pregnant women and one friend of a breastfeeding woman. Their ages varied from 27 to 72 years. All were housewives with a household income of one minimum salary who had not finished elementary school. The ages of the health professionals in FG3 varied from 23 to 50 years. Twelve were females and one was male. Most had been working for more than five years in the Family Health Strategy.

Analysis of the conversations resulted in the extraction of four themes that contextualized the strategies for promoting and supporting breastfeeding, how they should be implemented and by whom.

\section{Theme 1: Educational actions centered on dialogue involving the social support network during the vital cycle}

The statements indicated that the breastfeeding promotion and support strategies 
should be permeated by educational actions centered on guidance.

[...] guide, encourage, talk, teach, explain how to position the child to breastfeed [...] GF1.

[...] guide this youth, teach them how to breastfeed, they need someone to guide them [...] GF2.

[...] be advised about the things that will happen, also advise the mother, the neighbor, and also provide this information when the woman delivers the child [...] GF3.

The testimonies revealed that the groups did not only want guidance, but also educational action based on counseling, that is, characterized by an interpersonal relationship permeated by dialogue and active listening, valuing the exchange of information and helping the user to make self-care decisions.

[...] that approached us in a more respectful manner... they only believe that you have the obligation to breastfeed... we should be able to say what we feel, what we think, and not only listen to what they say... sometimes you want to say something but are not given the opportunity [...] GF1.

[...] we learn by asking, because one person speaking and everyone else listening does not work... everyone needs to speak up [...] GF2.

[...] the greater focus should be the woman, prepare the woman differently, have people listen, pay attention to everything she says [...] GF3.

The following statements evidenced that the educational actions within a dialogic context should be contemplated in the entire vital cycle, especially with teenagers pregnant for the first time:

[...] why not insert this (breastfeeding) early on, together with sexual education... since the beginning of prenatal care [...] GF3.
[...] today all the 12-, 13-year old girls are getting pregnant. They need more guidance... also (provide guidance) to the mother, grandmother, even to the teenage mothers, first-time mothers, second-time mothers... [...] GF2.

Bits of the conversations show that educational actions should be present in many scenarios, namely:

- Educational actions for promoting breastfeeding at home:

[...] (health agents) should visit pregnant women or those who just began to breastfeed. Health agents should go to their houses on the first 15 days of breastfeeding to help, preferably make many visits [...] GF1.

[...] Home visits are good, but they have to be more practical, since one thing is someone talking, another is someone showing how it is done [...] GF3.

- Educational actions for promoting breastfeeding during prenatal care visits:

[...] during the prenatal visits the nurses should show more, show a breast, show how it should be done [...] GF1.

[...] during prenatal visits, health professionals should make an anamnesis of breastfeeding. Since the first prenatal care visits we can already start working, since pregnancy [...] GF3.

- Educational actions for promoting breastfeeding in group meetings:

[...] gather women to talk, to teach a large group, each one sharing her opinion, women who are breastfeeding, who have already breastfed, who think about having children, those who are breastfeeding advising those who will breastfeed [...] GF1.

[...] meetings like this one, with a lot of people to talk about breastfeeding, I could share my experience with other mothers [...] GF2. 
[...] I think it would be good for us to work with a group of pregnant women and show them how to breastfeed, the initial care, explain exclusive breastfeeding, through dynamic groups [...] GF3.

When the participants were asked about who should be involved in the educational actions, it was clear that all the social support network actors should be involved.

[...] talk to relatives, friends, asking for help. The family... partner, mother, brother, sister [...] GF1.

[...] health agents, nurses, everyone, the friends, grandmothers and healthcare facility physicians, asking for help especially for the mother and husband [...] GF2.

[...] involve nurses, the entire team, relatives, pregnant and breastfeeding women, they could be multiplying agents (people who help to spread knowledge) [...] GF3.

\section{Theme 2: Educational actions at school}

For the health professional focal group, school was an important place for the cultural dissemination of breastfeeding. Schools should be included among other spaces that promote and support breastfeeding, so that promotion and support beings during childhood:

[...] introduce a school program in elementary school, insert breastfeeding early in the school curriculum [...] GF3.

[...] Why is it not part of the school curriculum? Promote breastfeeding in the school environment [...] GF3.

\section{Theme 3: Educational actions inserted in the media}

The groups considered that the media should be used for promoting and supporting breastfeeding. Television is a channel that caries information quickly and is potentially one of the entities that most promotes behavioral changes:

[...] more dissemination and more television campaigns. In the radio, include breastfeeding information in soap operas [...] GF1.

[...] / think television should be used more to talk about breastfeeding, today people watch a lot of television. The people do what the television tells them to do [...] GF3.

\section{Theme: 4 Counseling room in the Family Health Unit}

Basically, all focal groups made clear that women need support and help with the specific breastfeeding challenges and self-consciousness crises. The statements showed the need of ongoing counseling and a place in Family Health Units for instructing women facing breastfeeding difficulties:

[...] there should be a room at the Family Health Unit for women who are having problems breastfeeding or who do not want to breastfeed, with a nurse helping, advising, teaching how to hold the baby, how to breastfeed [...] GF1.

[...] If mothers had a problem and did not want to breastfeed, they could go to the Family Health Unit and get help [...] GF2.

\section{DISCUSSION}

Educational action was the main focus of the breastfeeding promotion strategy at the public level chosen by the participants. This action should be planned by disrupting the unidirectional transmission of information. The relationship between user and professional, and common sense and interpersonal exchanges must be valued. Dialogue permeated by active listening should be an essential instrument in the entire communication process. Not basing the teachinglearning relationship on dialogue is unfeasible 
because the human species cannot be mute, silent. Through the use of words, man can transform the world, moving from a naïve level of indignations, questionings and knowledge to a critical knowledge of reality ${ }^{4}$.

Although the focal groups used the word "to guide" to describe the action, its meaning is linked to the unidirectional way in which teaching occurs, differing from the precepts of dialogic educational practice. The objective of this practice is not only to inform to promote health, but also to change the existing knowledge. Dialogic communication in educational health practice aims to build knowledge that allows individuals to choose the most appropriate strategies for promoting, maintaining and recovering their health. Dialogue promotes an exchange of technical, scientific and popular bits of knowledge that users and professionals can use to build greater knowledge together ${ }^{12}$.

While attempting to build shared critical thought, spaces should be created to problematize bits of knowledge by reflecting about reality. Problematization seeks to overcome educational practices that are limited to the transmission of contents. This communication happens in a convergent manner, where all participants have the chance to share their experiences ${ }^{4}$.

In the need of exchanging knowledge, one realizes the importance of the participation and involvement of the social support network in the educational actions that promote and support breastfeeding. The involvement of relatives, friends, community leaders, health professionals, and health, religious and political services can influence the mother's decision to continue breastfeeding ${ }^{13,14}$. The social support network is an important source of support both for the recent and more experienced mothers. Different types of support can be offered in different circumstances; support may come as an advice, some practical help or even some comforting words ${ }^{15}$.
All actors of this study perceived the family as an active participant and also as a source of pressure on breastfeeding women. Even if, in some situations, the family does not have direct contact with health professionals, the mother's discourse allows health professionals to notice and infer that the family is responsible for the motheroriented messages related to the breastfeeding course. These messages are disclosed as the dietary and other conditions of the child are processed, and sometimes become ambiguous and contradictory. Among the family members, it seems that the child's father and grandmother are the central actors in this process.

The active presence of the partner is recognized as a support and encouragement for the breastfeeding process, especially regarding the daily care given to the mother and child. By sharing the responsibilities, the partner may feel that breastfeeding is not exclusive to the mother, but part of the chores shared by the couple. Grandmothers also have an important role in supporting and encouraging breastfeeding when they consider breast milk an essential food for the health and development of the baby. Nonetheless, grandmothers often lead breastfeeding women to doubt that breast milk is capable of meeting all the nutritional needs of the child ${ }^{16,17}$.

Dialogic educational actions covering the social support network cannot be confused with a mere negotiation among the parts, but a mobilization of people for a certain purpose. In this sense, the focal groups recommend that this mobilization should happen during home visits, since it is a way of bringing health professionals and users closer together. This visit is considered a space for listening and talking, a time of reception and bond creation, respecting the particularities of each family. The bond between health professionals and users emerges from the respect and trust built through constant contact and from gaining more awareness about the reality of the families, which provides a favorable environment for more humane care ${ }^{18}$. 
This respectful bond is essential when one intends to perform an educational practice based on ethical values, where the actors are supportive and join forces to find solutions to the problems at hand ${ }^{6}$.

Prenatal visits were pointed out as one of the opportunities for health professionals to identify the risk factors for early weaning and simultaneously perform educational actions by demonstrating breastfeeding management. This time was recognized as a reception time, since it allows dialogue and the free expression of doubts, feelings and experiences. Hence, health professionals need to allow women to expose their concerns, fears and expectations, so that they may take actions to help women overcome the challenges that appear during the breastfeeding process ${ }^{19}$.

Those who perform educational processes within this dialogic perspective help to strengthen the people with whom they interact. Only dialogue generates critical thinking capable of encouraging pregnant women to express their doubts and fears, and simultaneously help them to feel capable of being the agents of their own care, through critical and reflective analysis of their own problems ${ }^{20}$.

In addition to turning prenatal care visits into a breastfeeding promotion scenario, the participants mentioned the need of group meetings, allowing women, together with the social support network, to benefit from participatory education. Group activities may give women the opportunity to share their experiences and expectations with respect to breastfeeding. The formation of breastfeeding support groups with people from the community is one of the steps of the Iniciativa Unidade Básica Amiga da Amamentação (IUBAAM), which aims to promote and support breastfeeding by mobilizing primary healthcare units to adopt the "Dez Passos Para o Sucesso de Amamentação" 21.

The suggested group meetings are similar to the culture circle instituted by Paulo Freire in the 1960s, as an instrument for learning and strengthening bonds through dialogue. Culture circle in the dialogic concept is a circular space for expressing the self. Therefore, it is a contemplative and participative space. It is a method of discussing a given topic using various forms of expression, aiming to exchange information democratically, efficiently and quickly, allowing the development of activities that promote its achievement. Therefore, this method opposes banking education, that is, one where knowledge is deposited without reflection and questioning ${ }^{22,23}$.

Among breastfeeding promotion strategies, the suggestion of introducing educational actions in schools was also evidenced. This proposal of including health promotion strategies in the school curriculum is not new. Education and health have been coming closer together since the 1970s through legal instruments, such as the Alma Ata Declaration, Ottawa Conference and strategies such as the Family Health Program, among others. The sooner the importance of breastfeeding is internalized, more favorable and positive this practice becomes for the individual. Thus, it is essential to begin promoting breastfeeding during childhood. School is the main institutionalized environment of the pedagogic and teaching-learning process, of socialization and growth, where one acquires cardinal health-promoting values. Yet, for this to happen, the school curriculum needs to be flexible, the school staff needs to be trained and health professionals and the local community need to collaborate ${ }^{24,25}$.

The use of the media was another strategy considered to have social impact for implementing educational actions. The media has much influence in people's minds and behaviors, contributing substantially to changes or maintenance of social values and practices ${ }^{26}$.

The focal groups also talked about the need of counseling rooms available 24 hours a day at the Family Health Units to clarify doubts on breastfeeding management and difficulties.

Health professionals should give breastfeeding women the opportunity to obtain 
counseling, giving them the strength to deal with pressures, increasing their self-confidence and self-esteem and preparing them for decisionmaking ${ }^{27}$.

\section{FINALCONSIDERATIONS}

Breastfeeding promotion and support strategies should be centered on dialogue and active listening and begin during elementary school. They should also always be present in the Family Health Strategy, involving all actors of the social support network in all visits done during the pregnancy-puerperal cycle. These strategies may disrupt the unidirectional transmission of educational breastfeeding practices and recognize that women and their families are knowledgeable and capable of establishing dialogue with the health service. Accordingly, breastfeeding promotion and support strategies can be used for planning educational activities and implementing new practices in primary healthcare units.

Research action contributed to a more comprehensive understanding of humanization in educational action, recognizing the need of changing the relationship between health professionals and users and learning that the dialogic model in educational actions corresponds to the more pertinent model for pro-breastfeeding activities.

\section{O LLABORATORS}

All authors participated in the study conception, data analysis and interpretation, and writing of the article. FMP LINHARES was responsible for developing the field work and collecting data.

\section{REFERENCES}

1. World Health Organization. Global strategy for infant and young child feeding. Geneva: WHO; 2003.
2. Brasil. Ministério da Saúde. Política Nacional de promoção, proteção e apoio ao aleitamento materno. Brasilia: MS; 2008 [acesso 2012 jul 13]. Disponível em: <http://portal.saude.gov.br/portal/ saude/visualizar_texto.cfm?idtxt=37381>.

3. Lee E. Health, morality and infant feeding: British mothers' experiences of formula milk use in the early weeks. Sociol Health Illness. 2007; 16(7): 1075-90. doi: 10.1111/j.1467-9566.2007.010 20.x.

4. Freire P. Pedagogia do oprimido. $46^{\mathrm{a}}$ ed. Rio de Janeiro: Paz e Terra; 2006.

5. Alvim NAT, Ferreira MA. Perspectiva problematizadora da educação popular em saúde e a enfermagem. Texto Contexto-Enferm. 2007; 16(2):315-19. doi: 10.1590/S0104-07072007000200015.

6. Freire P. Pedagogia da esperança: um reencontro com a pedagogia do oprimido. $9^{a}$ ed. Rio de Janeiro: Paz e Terra; 2002.

7. Le Boterf G. Pesquisa participante: propostas e reflexões metodológicas. In: Brandão $C R$, organizador. Repensando a pesquisa participante. São Paulo: Brasiliense; 1999.

8. Thiollent M. Metodologia da pesquisa-ação. $15^{a}$ ed. São Paulo: Cortez; 2007.

9. Krueger RA, Casey MA. Focus groups: A practical guide for applied research. $4^{\text {th }}$ ed. Thousand Oaks (CA): SAGE; 2009.

10. Fontanella BJB, Luchesi BM, Saidel MGB, Ricas J, Turato ER, Melo DG. Amostragem em pesquisas qualitativas: proposta de procedimentos para constatar saturação teórica. Cad Saúde Pública. 2011; 27(2):389-94. doi: 10.1590/S0102-311X20 11000200020

11. Bardin L. Análise de conteúdo. São Paulo: Edições 70; 2011.

12. Ferreira MLSM, Cotta RMM, Lugarinho R, Oliveira MS. Construção de espaço social unificado para a formação de profissionais de saúde no contexto do sistema único de saúde. Rev Bras Educ Med. 2010; 34(2):304-9. doi: 10.1590/S0100-5502201 0000200016

13. Barona-Vilar C, Escriba-Aguir V, Ferrero-Gandía R. A qualitatative approach to social support and breast-feeding decisions. Midwifery. 2009; 25(2):187-94. doi: 10.1016/j.midw.2007.01.013.

14. Teixeira MA, Nitshke RG, De Casperi P, Siedler MJ. Significados de avós sobre a prática do aleitamento materno no cotidiano familiar: a cultura do querer-poder amamentar. Texto Contexto-Enferm. 2006; 15(1):98-106. doi: 10.1590/S0104-070720060001 00012. 
15. Rapoport A, Piccinini CA. Apoio social e experiência da maternidade. Rev Bras Crescimento Desenvolv Hum. 2006; 16(1):85-96. doi: S0104 1282200600 0100009.

16. Pontes CM, Osório MM, Alexandrino AC. Building a place for the father as an ally for breast feeding. Midwifery. 2009; 25:195-202. doi: 10.1016/ j.midw.2006.09.004.

17. Pontes CM, Alexandrino AC, Osório MM. Participação do pai no processo da amamentação: vivências, conhecimentos, comportamentos e sentimentos. J Pediatr. 2008; 84(4):357-64. doi: 10.22 23/JPED.1814.

18. Albuquerque ABB, Bosi MLM. Visita domiciliar no âmbito da Estratégia Saúde da Família: percepções de usuários no Município de Fortaleza, Ceará, Brasil. Cad Saúde Pública. 2009; 25(5):1103-12. doi: 10.1590/S0102-311X2009000500017.

19. Shimizu HE, Lima MG. As dimensões do cuidado pré-natal na consulta de enfermagem. Rev Bras Enferm. 2009; 62(3):387-92. doi: 10.1590/S003 4-71672009000300009.

20. Freire P. Educação como prática da liberdade: a sociedade brasileira em transição. Rio de Janeiro: Paz e Terra; 2000.

21. Oliveira MIC, Gomes MAM. As Unidades Básicas Amigas da Amamentação: uma nova tática no apoio ao aleitamento materno. In: Rego JD, editor, Aleitamento materno: um guia para pais e familiares. $2^{a}$ ed. São Paulo: Atheneu; 2006.
22. Freire P. Educação como prática a liberdade. $30^{\mathrm{a}}$ ed. Rio de Janeiro: Paz e Terra; 2007.

23. Boehs AE, Monticelli M, Wosny IBSH, Grisotti M. A interface necessária entre enfermagem, educação em saúde e o conceito de cultura. Texto ContextoEnferm. 2007; 16(2):307-17. doi: 10.1590/S0104-0 7072007000200014 .

24. Montrone AVG, Arantes Cl, Lébeis NM, Pereira TACF. Promoção da amamentação por crianças do ensino fundamental. Interface. 2009; 13(31): 449-59. doi: org/10.1590/S1414-3283200900040 0017.

25. Bottaro SM, Giugliani ERJ. Estudo exploratório sobre aleitamento materno entre escolares de quinta série do Ensino Fundamental. Cad Saúde Pública. 2008; 24(7):1599-608. doi:10.1590/S0102-311X2 008000700015 .

26. Bydlowsky CR, Westphal MF, Pereira IMTB. Promoção da saúde: porque sim e porque ainda não. Saúde Soc. 2004; 13(1):14-24. doi: 10.1590/S01 04-12902004000100003.

27. Oliveira MIC, Souza IEO, Santos EM, Camacho LAB. Avaliação do apoio recebido para amamentar: signi-ficados de mulheres usuárias de Unidades Básicas de Saúde do estado do Rio de Janeiro. Ciênc Saúde Coletiva. 2010; 15(2):599-608. doi:10.1590/ S141 3-81232010000200036.

Received on: 31/10/2011

Final version on: 30/10/2012

Approved on: 12/11/2012 